\title{
De toekomst van de Mediageschiedenis
} (1993-1994)

Op 26 november 1993 vond in het statige gebouw van de Koninklijke Nederlandse Akademie van Wetenschappen het symposium 'De Toekomst van de Mediageschiedenis' plaats. De middag was georganiseerd door de Vereniging Geschiedenis Beeld a Geluid en de Commissie Bevordering Mediahistorisch Onderzoek (свмо) van de Sociaal-Wetenschappelijke Raad, ondersteund door de Akademie en de Stichting Film en Wetenschap. Het overgrote deel van de vijftig genodigden had aan de uitnodiging gevolg gegeven. In dit artikel treft $u$ een samenvatting aan van de lezingen, alsmede een summiere impressie van de discussie die op de lezingen volgde.

De gedachte een openbaar debat over de stand van zaken in de mediageschiedenis te organiseren rees - min of meer gelijktijdig en onafhankelijk van elkaar - bij verschillende personen. Zij vroegen zich, kort gezegd, af waar het met de verschillende takken van deze discipline heen moest. Want terwijl de infrastructuur en toegankelijkheid van het materiaal de laatste jaren aanmerkelijk verbeterden, leek het wetenschappelijk onderzoek met name in vergelijking met andere landen achter te blijven. Natuurlijk, er is een Jaarboek Mediageschiedenis en er zijn tijdschriften, die soms mooie stukken het licht doen zien, maar alles tezamen genomen is het gevaar niet denkbeeldig, dat de beoefening van de mediageschiedenis blijft steken in een bepaalde benadering en op een bepaald niveau.

Op grond van dergelijke overwegingen en geluiden leek het de Vereniging GBG en de Commissie Bevordering Mediahistorisch Onderzoek nuttig een vijftigtal beoefenaren van de pers-, film- en omroepgeschiedenis, plus een aantal vertegenwoordigers uit de hoek van de communicatiewetenschap en de nieuwe en contemporaine geschiedenis uit te nodigen voor een open debat over de toekomst van de mediageschiedenis.

Daarbij zou het ten eerste moeten gaan om een evaluatie van de huidige stand van zaken, en, in de tweede plaats, om de vraag welke initiatieven er eventueel zouden kunnen worden ontplooid om daarin verbetering aan te brengen en welke rol de verschillende organisaties en instellingen daarbij zouden kunnen spelen. De basis van het debat zou worden gelegd door een inleidende lezing en een vijftal commentaren van ongeveer een kwartier. De voorbereidingscommissie had zowel de sprekers als de deelnemers ruim tevoren een aantal prikkelende stellingen en voorstellen toegezonden (zie de teksten in de kaders op de volgende pagina's), plus het inleidende artikel van Frank van Vree in het jongste Jaarboek Mediageschiedenis - 'Mediageschiedenis in Nederland - achtergronden en perspectieven'.

In de stellingen en toelichting daarop werd in tamelijk sombere toon gewag gemaakt van de 
tekortkomingen van de mediageschiedenis. Al voor het symposium bleek dat dit sommigen in het verkeerde keelgat was geschoten (zie bijvoorbeeld het artikel van Bert Bogenkamp elders in dit nummer): zij vatten de stellingen op als een neerhalen van deze of gene opleiding, van hun eigen specialisme; sommigen voelden zich zelfs persoonlijk aangevallen. Aan het begin van de discussiemiddag maakte de voorbereidingscommissie de deelnemers duidelijk dat zoiets natuurlijk nooit de bedoeling was geweest: het ging hier immers niet om een aanval op individuele onderzoekers, maar simpelweg om enkele stellingen die het debat op gang moesten brengen - stellingen die bovendien betrekking hebben op structurele problemen in dit vakgebied als geheel, van het oudere en bredere specialisme van de persgeschiedenis en de wat jongere en zeker niet onverdienstelijke filmgeschiedenis tot aan de nog nauwelijks existerende omroepgeschiedenis.

De vraag had ook anders gesteld kunnen worden: waarom zouden GBG, de Stichting Film en Wetenschap en de Commissie Bevordering Mediahistorisch Onderzoek zoveel moeite doen voor de openstelling van de rijke audiovisuele collecties, terwijl het feitelijk aantal onderzoekers op de vingers van een hand te tellen is? Of nog anders: waarom treft men zo weinig mediahistorici aan onder de AIO's en onder universitaire medewerkers, terwijl mediageschiedenis het laatste decennium is uitgegroeid tot een van de meest populaire terreinen voor doctoraalscripties? En hoe zit het met de communicatiewetenschap in Nederland?

\section{Mediageschiedenis als discourse-analyse}

De rij van sprekers werd geopend door Robert Sklar, hoogleraar 'Cinema' aan de Universiteit van New York en auteur van enkele belangwekkende studies op het gebied van filmgeschiedenis. Zijn bijdrage, getiteld 'Media en "massa”, Kennis en Macht', was sterk theoretisch van aard. Als historici kunnen we het ons eenvoudigweg niet permitteren ons niet bezig te houden met een reflectie op ons werk, zo begon Sklar zijn betoog, zeker niet in het geval van de mediageschiedenis. Het gaat hier immers om een gebied zonder een lange geschiedenis, zonder vaste conventies en debatten. Men moet zich zeer goed bewust zijn van de keuzen die aan een werk ten grondslag liggen: hoe wordt geselecteerd uit de zee van materiaal en hoe wordt het onderwerp gerelateerd aan de 'context' waarin de communicatie plaatsvindt? Een nadere beschouwing van de eigen uitgangspunten is cruciaal: ze impliceren immers de opvattingen aangaande het specifieke object van mediageschiedenis en de afbakening ten opzichte van de brede sociale en culturele 'omgeving'.

Onder verwijzing naar een artikel van Michel Foucault uit I968, 'Politics and the Study of Discourse', ging Sklar vervolgens uitvoerig in op de vraag hoe de objecten van de cultuur- en ideeëngeschiedenis - en daarmee van de media - gezien moeten worden: als tekens, als producten van de samenleving of als symbolische expressies. Foucault's oplossing van deze vraag lag, zoals bekend, in 'een analyse van het discourse zelf'. Volgens Sklar biedt zo'n benadering ook voor de studie van de geschiedenis van de media meer perspectief dan benaderingen die bijvoorbeeld uitgaan van de sociale of culturele context. Juist in een analyse van de specifieke 'taal' - of, juister gezegd, van de discursieve praktijken - ligt het eigen karakter van de mediageschiedenis besloten. Ter illustratie wees Sklar op zijn boek City Boys. Daarin voert hij drie acteurs ten tonele - Cagney, Bogart en Garfield - die rond I930 als 'nationale typen' in de Amerikaanse populaire cultuur opdoken, en die in de eerste plaats beschouwd kunnen worden als sociale 
constructies, als product van bepaalde conventies, van creatieve en commerciële impulsen en ideologische motieven.

De taak van de mediahistorici, zo betoogde Sklar, ligt primair in het analyseren van media-typische constructies en het verbinden van deze aan andere discursieve praktijken. Een andere taak ligt in de reflectie op de 'taal' en de ontwikkeling van het vakgebied zelf, i.c. de mediageschiedenis. In de tweede helft van zijn betoog trachtte Sklar door het problematiseren van een centraal begrip - 'massa' - de nauwe onderlinge verwevenheid van deze taken te laten zien.

\section{DE STELLINGEN}

I. De grondbegrippen en theorieën van de communicatiewetenschap kunnen niet eenvoudigweg aan het verleden worden opgelegd. Communicatiegeschiedenis zal in die zin voor alles historisch moeten zijn.

2. Wanneer wordt gepleit voor 'communicatiegeschiedenis' of 'mediageschiedenis' dan gaat het niet om een simpele toepassing van theorieën, generalisaties en modellen uit de sociale wetenschap, maar om een pleidooi voor een verandering van het perspectief. Zo moet er meer aandacht komen voor de sociaal- en cultuurhistorische context waarbinnen de media en hun producten functioneren, alsmede voor aspecten van betekenis en representatie.

3. De meeste mediahistorische studies van Nederlandse oorsprong zijn theoretisch niet of nauwelijks onderbouwd, zeker in vergelijking met buitenlandse publicaties. Daarin ligt een van de oorzaken van het ontbreken van discussies en, tegelijkertijd, van het weinig hoogstaande niveau van bijvoorbeeld de meeste doctoraalscripties: ieder lijkt het wiel opnieuw uit te moeten vinden. Dit maakt het tevens moeilijk de discipline te grondvesten.

4. Mediageschiedenis is (nog te zeer) een begrip, waarmee het verschil in opvattingen, tradities en interessen tussen persgeschiedenis, omroepgeschiedenis, filmgeschiedenis, fotogeschiedenis en andere, meer algemene historische specialismen wordt verdoezeld.

5. Het lijkt er op dat tal van ontwikkelingen in de sociale en culturele geschiedschrijving, literatuurwetenschap of sociologie aan de historici van uiteenlopende specialismen voorbij zijn gegaan. Verouderde kwantitatieve methoden gaan bijvoorbeeld nog door voor revolutionair.

6. Het mediahistorisch onderzoek is nog altijd tamelijk eenzijdig georiënteerd, hetzij institutioneel, hetzij zuiver kunsthistorisch, waarbij men zich bovendien nauwelijks buiten het eigen beperkte specialisme waagt. Het communicatieve perspectief ontbreekt in veel gevallen geheel. Bij de institutionele, niet zelden encyclopedische studies - die de afzonderlijke, sterk verkokerde disciplines in veel gevallen dreigen te overwoekeren - krijgt men vaak de indruk dat het net zo goed over willekeurig welk ander product in plaats van over film of krant zou kunnen gaan.

7. Dat de televisie- en radiogeschiedenis nauwelijks zijn ontwikkeld heeft mede te maken met het traditionele dédain voor populaire media en de inhoud van de programma's. 
8. Het gebrek aan coördinatie of overleg met betrekking tot onderwijs en onderzoek - ondanks Свмо, GвG, Stichting Mediageschiedenis en andere instellingen op dit gebied - dragen ertoe bij dat in deze situatie nauwelijks verbetering optreedt. Het ontbreken van een kwalitatief hoogstaand tijdschrift speelt hierbij ongetwijfeld ook een rol.

9. Massacommunicatie in Nederland is nog altijd een 'vak zonder verleden': de historische dimensie wordt vrijwel genegeerd en de communicatiewetenschap zelf levert nauwelijks impulsen.

\section{HOE VERDER}

Om de discussie enigszins in banen te leiden had de voorbereidingscommissie de deelnemers enkele concrete plannen voorgelegd. Deze behelsden een verdergaande samenwerking en bundeling van krachten; de wereld van Nederlandse specialisten op het terrein van de geschiedenis van pers, omroep, film en foto is immers te klein en de belangen zijn te groot om in afzonderlijke groepen te blijven zitten. Een belangrijke stap in de goede richting zou kunnen liggen in de (her)vorming van een Stichting Mediageschiedenis, die zou kunnen worden gedragen door de wetenschappelijke instellingen, verenigingen en bewaarplaatsen. Als samenwerkingsverband zou deze Stichting zich moeten toeleggen op de ontwikkeling van een onderzoeksbeleid.

De behartiging van de gemeenschappelijke belangen, de organisatie van congressen en de uitgave van een nieuw twee-, drie- of viermaal per jaar verschijnend tijdschrift. De Stichting zou een actief dagelijks bestuur moeten hebben met enige secretariële ondersteuning.

Voor zover dat nog niet het geval is, zouden inleidende cursussen over mediageschiedenis en de omgang met audiovisuele bronnen een verplicht onderdeel moeten zijn, zowel binnen de programma's van nieuwste en eigentijdse geschiedenis, als binnen de curricula van communicatiewetenschap en film- en televisiewetenschappen.

Als laatste punt werd voorgesteld te komen tot handzame overzichtswerken en 'apparaten' op het terrein van de mediageschiedenis.

\section{Representatie als bindend thema}

William Uricchio, zeer onlangs aangesteld als hoogleraar Film- en Televisiegeschiedenis aan de Universiteit Utrecht, startte zijn betoog met een uitvoerige beschouwing over nieuwe benaderingen in de beoefening van de mediageschiedenis. Daarbij nam hij niet de Nederlandse situatie als uitgangspunt, maar de recente ontwikkelingen in de sociale en culturele wetenschappen in het algemeen. Deze worden beheerst door twee tendensen, aldus Uricchio: enerzijds is er sprake van groeiende tegenstellingen binnen de afzonderlijke disciplines met betrekking tot perspectieven en kennistheoretische uitgangspunten, anderzijds ziet men juist een toenemende samenwerking tussen disciplines.

In weerwil van de voortschrijdende academische specialisatie manifesteert zich een nieuwe generatie onderzoekers, die zich met elkaar verwant voelen en zich over de grenzen van de traditionele disciplines heen bewegen op het terrein van representatie, verhaal en receptie. Deze 
ontwikkeling kan niet los worden gezien van de postmodernistische opvattingen die sedert de jaren zestig in brede zin opgang doen. Nieuwe disciplines zijn ontstaan op het snijpunt van deze grensoverschrijdingen, met name rond thema's als 'gender' en 'popular culture' die eerder een marginaal bestaan leden.

Het vervolg van Uricchio's betoog spitste zich toe op de mediageschiedenis en hij trachtte duidelijk te maken waarin de benadering van deze nieuwe generatie zich onderscheidt van meer traditionele uitgangspunten. In de oude interpretaties ging het vooral om wat de tekst (beeld, geluid) betekende - in de nieuwe analyse om hoe deze werkt. Dit onderscheid komt vooral scherp naar voren wanneer, bijvoorbeeld, de traditionele filmwetenschap wordt vergeleken met de jongere en veel breder georiënteerde 'television studies': de laatste richten zich veeleer op discourse-analyse en publieksonderzoek.

De traditionele geschiedschrijving, aldus Uricchio, concentreerde zich op het gedrukte woord als 'bewijsmateriaal', als medium in engere zin; deze benadering staat in meer dan een opzicht tegenover een geschiedenis die zich richt op de productie en ontvangst van betekenissen, kortom, op discursieve praktijken. Toch zou men kunnen betogen dat deze benaderingen in wezen eerder complementair dan tegengesteld zijn.

Binnen de studie van de media lijkt de aanvankelijke gerichtheid op de afzonderlijke communicatietechnieken (pers, film, radio, televisie) ondertussen aan betekenis te verliezen, ten gunste van een bredere benadering gebaseerd op representatie, betekenis en verhaal. Met name in het mediahistorisch onderzoek kan dit vruchtbaar zijn, zo verklaarde Uricchio: het centrale punt is representatie, de processen 'by which meaning is given form, circulated, and negotiated'. Zeker vanuit een historisch perspectief is het weinig zinvol de ene representatievorm (film, krant) te isoleren van een veel breder systeem.

Uricchio besloot zijn bijdrage met erop te wijzen dat er geen reden is somber te zijn over de vooruitzichten voor het vakgebied in Nederland. Er zijn goede onderzoekers en faciliteiten, terwijl het land in wetenschappelijk opzicht gunstig is gelegen. Toch zal de ontwikkeling van dit voor de moderne geschiedenis zo belangrijke onderzoeksveld inspanningen vergen, op straffe van marginalisering.

\section{Mediageschiedenis als kunst}

De bijdrage van de Rotterdamse hoogleraar en journalist Henri Beunders, onder de titel 'De media als mysterie', stond vooral in het teken van het vrijwel ondoordringbare karakter van de moderne communicatie en een zekere gereserveerdheid jegens al te ambitieuze plannen voor de organisatie van het onderzoek.

Beunders signaleerde binnen de communicatiewetenschap een wending naar het verleden en verwonderde zich erover dat er niet meer sprekers uit die hoek waren uitgenodigd. Dat de communicatiewetenschap haar eigen onderzoek tegenwoordig als problematisch ervaart, vloeit voort uit het feit dat binnen het op positivistische grondslag geschoeide onderzoek te zeer voorbijgegaan werd aan het inzicht dat media pas werkelijk betekenis krijgen in hun maatschappelijke en historische context. Onder historici - van oudsher descriptief ingesteld maar wèl gericht op die bredere context - nam Beunders daarentegen juist een grotere behoefte aan theorie waar. Daarbij lijken zij hun traditionele dédain voor de massamedia te hebben overwonnen en hun achterstand met spoed te willen inhalen. 
Inmiddels bespeurde Beunders - ook bij de opstellers van de stukken van het symposium 'een bijna mystiek verlangen' naar een totaalrecept voor het bedrijven van mediaonderzoek, om zo achter de betekenis van de media te komen. Dit laatste is evenwel niet zo eenvoudig: 'om in woorden dichter bij het geheim van de betekenis te komen, moet je van heel goeden huize komen', aldus Beunders. 'De mediawetenschapper moet in feite een boekhouder, een chirurg, een allesweter en een dichter tegelijk zijn, kortom een kunstenaar'.

Wat de praktische aanbevelingen betreft zag Beunders weinig belemmeringen om te komen tot een tijdschrift; ten aanzien van bundeling van het onderzoek was hij aanmerkelijk sceptischer. Grote instituten en geldstromen zouden wel eens een hindernis kunnen blijken te zijn voor oorspronkelijk onderzoek, dat vaak individueel en buiten de gevestigde wetenschappelijke kaders om tot stand komt.

\section{Mediageschiedenis als gewone geschiedenis}

Doeko Bosscher, hoogleraar contemporaine geschiedenis aan de Rijksuniversiteit Groningen, reageerde in zijn referaat op elke stelling afzonderlijk. Zijn reacties worden voor alles gekenmerkt door een huivering ten aanzien van de vorming van onderzoekstheorieën en -methoden. In die zin vormt Bosschers reactie inderdaad een aardige weerspiegeling van hetgeen binnen de (Nederlandse) historisch-wetenschappelijke wereld gemeengoed is. Hij kan de stelling verdedigen dat historici en communicatiewetenschappers wat aan elkaar kunnen hebben, maar hij maakt een groot voorbehoud daar waar zijns inziens het gevaar loert van een klakkeloos overnemen door historici van theorieën uit de communicatiewetenschap. Het is al mooi wanneer beide disciplines elkaars wetenschappelijk idioom wat beter zouden leren kennen om vervolgens te ontdekken dat ze meer op elkaar lijken dan ze misschien nu denken.

Bosscher illustreerde deze opvatting met zijn reactie op stelling 4 (mediageschiedenis is een begrip dat verschillen tussen gerelateerde deeldisciplines en de meer algemene historische specialismen versluiert) door te stellen dat mediahistorici eigenlijk moeten doen wat 'gewone' historici ook doen, met dat verschil dat zij een ander 'deelterrein' van de geschiedenis tot hun territorium rekenen. Toch oordeelt Bosscher positief over de poging van de organisatoren een begin te maken met het definiëren van een interessante nieuwe loot aan de boom die geschiedenis heet.

\section{De nieuwe filmgeschiedenis}

Professor Thomas Elsaesser, hoogleraar Film- en Televisiewetenschap aan de Universiteit van Amsterdam, karakteriseerde de jaren zeventig en tachtig als de tijd waarin men in de internationale filmwetenschappelijke wereld gefixeerd was op theorievorming; deze theorieën waren niet goed te begrijpen voor wie buiten deze specifieke discipline stond. Het gevolg was dat het vak steeds sterker in vele welhaast autarkische deelgebieden, zoals semiotiek en psychoanalyse, werd gesplitst.

De wens van de filmhistorici, eind jaren tachtig begin jaren negentig, was juist om deze fracties weer bij elkaar te brengen: filmgeschiedenis schrijven is het hoogste doel, de verschillende deeldisciplines dienen te worden aangewend wanneer zij ons een beter geschakeerd beeld kunnen geven van de filmgeschiedenis. 
Elsaessers toonzetting is vooralsnog pessimistisch: er zijn mogelijkheden genoeg om te komen tot betere samenwerking en tot interdisciplinaire projecten. Waar het momenteel aan ontbreekt zijn de financiële en personele randvoorwaarden om deze plannen te verwezenlijken.

\section{Wat heeft mediageschiedenis eigenlijk te bieden?}

Professor James Stappers, hoogleraar Communicatiewetenschap aan de Katholieke Universiteit Nijmegen, vraagt zich af waarom sommige theorieën uit de communicatiewetenschap (hoewel hij liever spreekt over hypotheses, aanzetten tot theorieën, die nog getoetst moeten worden) niet bruikbaar zouden zijn binnen de context van het historisch onderzoek; hij begrijpt deze koudwatervrees niet. Natuurlijk mogen begrippen en termen nooit eenvoudigweg worden overgeplaatst, noch mogen zij onder dwang worden opgelegd. Hoewel Stappers erkent dat sommige theorieën niet of nauwelijks meer geverifieerd kunnen worden aangezien bepaalde verkenningen niet meer op het verleden kunnen worden uitgevoerd, kunnen naar zijn mening bepaalde massacommunicatieve onderzoeksmethoden uit de tegenwoordige tijd heel best binnen het historische onderzoek worden gebruikt.

Door middel van en aantal hulp- en tegenstellingen bekritiseert Stappers de naar zijn mening foutieve uitgangspunten waarmee de organisatoren de disciplines Communicatiewetenschap en Geschiedwetenschap tegenover elkaar hebben geplaatst. Beide disciplines schuren wel degelijk tegen elkaar aan: een mooi voorbeeld is gelegen in de bestudering van het verzuilde omroepbestel. Wel erkent hij dat de Communicatiewetenschap zich niet met haar eigen verleden bemoeit en ziet daar een duidelijke leemte.

Stappers eindigt zijn verhaal met de conclusie dat gestart kan worden met het dichten van de - smalle - kloof tussen beide disciplines wanneer erkend wordt dat de ene wetenschap nooit een primaat mag hebben boven de andere: 'Er wordt wel gezegd dat de Communicatiewetenschap zelf (dat woordje maakt veel goed) nauwelijks impulsen levert, maar de vraag is natuurlijk wie moet wie de impulsen leveren. Mag het ook andersom zijn?'

\section{Moeizame discussie}

Hoewel de zes inleidingen en de conferentiestukken voldoende stof leken te bieden voor een pittige gedachtewisseling en de voorzitter, de Amsterdamse historicus Hans Blom, de aanwezigen uit hun tent trachtte te lokken, kwam de discussie het laatste uur slechts moeizaam van de grond. Wel vielen er hier en daar harde woorden. Zo voelde men zich in de hoek van de filmgeschiedenis en de communicatiewetenschap duidelijk tekort gedaan door de scherpe formuleringen. Op grond van deze geluiden werd op een gegeven moment dan ook de stelling geopperd, dat een basis voor verdere samenwerking op mediahistorisch gebied feitelijk ontbreekt - een gedachte die onder tumult werd verworpen als voorbarig en destructief.

Pas kort voor het einde van de middag kreeg de discussie alsnog enig perspectief. Hoewel deze vergadering natuurlijk niet bij machte was om besluiten te nemen, leek men in te kunnen stemmen met de volgende plannen.

Ten eerste zouden de organisaties en bestaande bladen, met name de Stichting Film en Wetenschap, de vereniging Geschiedenis, Beeld en Geluid, en het Jaarboek Mediageschiedenis, 
zich moeten buigen over mogelijkheden tot versterking van de publicitaire middelen. Om het onderzoek te stimuleren zouden met name vanuit de Commissie Bevordering Mediahistorisch Onderzoek initiatieven kunnen worden ontplooid om te komen tot voorstellen voor onderzoek; concreet zou het daarbij kunnen gaan om het ontwerpen van een samenhangend voorstel dat geschikt is om te worden ingediend bij de Nwo/sho (bijvoorbeeld onder de titel 'Massacultuur en media').

Zo kon dit symposium, waar gemengde gevoelens duidelijk de overhand leken te hebben, toch nog afgesloten worden met een positief geluid. 